Article

\title{
Growth of $\beta-\mathrm{NaYF}_{4}: \mathrm{Eu}^{3+}$ Crystals by the Solvothermal Method with the Aid of Oleic Acid and Their Photoluminescence Properties
}

\author{
Jianhua Huang ${ }^{1,2,+}$, Xiaojing Wang ${ }^{1,+}$, An Shao ${ }^{3,+}$, Guoping Du ${ }^{1, *}$ and Nan Chen ${ }^{1, *}$ \\ School of Materials Science and Engineering, Nanchang University, Nanchang 330031, China \\ 2 Hunan Engineering Laboratory for Control and Optimization of PV Systems, Hunan Vocational Institute of \\ Technology, Xiangtan 411104, China \\ 3 Queen Mary School, Nanchang University, Nanchang 330031, China \\ * Correspondence: guopingdu@ncu.edu.cn (G.D.); nanchen@ncu.edu.cn (N.C.) \\ + These authors contributed equally to this work.
}

Received: 16 October 2019; Accepted: 6 November 2019; Published: 11 November 2019

check for updates

\begin{abstract}
Lanthanide-doped hexagonal $\beta-\mathrm{NaYF}_{4}$ crystals have received much attention in recent years due to their excellent photoluminescence properties. However, lanthanide-doped $\beta-\mathrm{NaYF}_{4}$ crystals with micron and submicron scales as well as uniform morphology have received less attention. In this study, $\mathrm{Eu}^{3+}$-doped $\beta-\mathrm{NaYF}_{4}\left(\beta-\mathrm{NaYF}_{4}: \mathrm{Eu}^{3+}\right)$ crystals of micron and submicron size scales were synthesized using the solvothermal method with ethylene glycol as the solvent. The $\beta-\mathrm{NaYF}_{4}: \mathrm{Eu}^{3+}$ crystals were highly crystallized. A comparison of the characteristics of the $\beta-\mathrm{NaYF}_{4}: \mathrm{Eu}^{3+}$ crystals synthesized with and without the use of oleic acid as a surfactant was conducted. It was found that the utilization of oleic acid as a surfactant during their synthesis greatly decreased their particle size from micron to submicron scale, while adding a small amount of ethanol further reduced their particle size. In addition, they exhibited much smoother surfaces and more uniform morphologies, which were hexagonal prism bipyramids. The microstructural characteristics and photoluminescence properties of the $\beta-\mathrm{NaYF}_{4}: \mathrm{Eu}^{3+}$ crystals were studied in detail. Results showed that $\beta-\mathrm{NaYF}_{4}: \mathrm{Eu}^{3+}$ crystals prepared with the aid of oleic acid as a surfactant during their synthesis exhibited stronger photoluminescence.
\end{abstract}

Keywords: lanthanide-doped fluoride; $\mathrm{Eu}^{3+}$-doped $\beta-\mathrm{NaYF}_{4}$; photoluminescence; solvothermal method

\section{Introduction}

$\mathrm{NaYF}_{4}$ has two polymorphic forms: $\alpha$ - (cubic) and $\beta$-phase (hexagonal) structures. In recent years, $\mathrm{NaYF}_{4}$ - especially the $\beta$ phase - has been considered one of the most effective host materials for performing multicolor down-conversion (DC) and up-conversion (UC) photoluminescence of lanthanide ions $\left(\mathrm{Ln}^{3+}\right)$ due to its unique properties [1], including low phonon energy $\left(<400 \mathrm{~cm}^{-1}\right)$ [2], high thermal and optical stability, good transparency, low non-radiative decay rate, and high radiative emission efficiency [3]. $\mathrm{Ln}^{3+}$-doped $\mathrm{NaYF}_{4}$ phosphors have been extensively studied [4-10] in both micro- and nano-sized scales because of their potential applications in light-emitting diodes (LEDs) [11], lasers [12], display devices [9], biological labels [13-15], solar cells [16,17], and many others.

The space groups of $\alpha$ - and $\beta-\mathrm{NaYF}_{4}$ are Fm3m $(\mathrm{Z}=4)$ and P6 $(\mathrm{Z}=1)$, respectively. The $\alpha-\mathrm{NaYF}_{4}$ is isomorphic with $\mathrm{CaF}_{2}$ in which the sites of $\mathrm{Ca}^{2+}$ ions are substituted randomly by $1 / 2 \mathrm{Na}^{+}$ions and $1 / 2 \mathrm{Y}^{3+}$ ions and the $\mathrm{O}_{\mathrm{h}}$ symmetry of the cationic site has been retained [18]. Three types of cation sites exist in $\beta-\mathrm{NaYF}_{4}$ : 1a sites are occupied by $\mathrm{Y}^{3+}$, 1f sites are occupied by $1 / 2 \mathrm{Y}^{3+}$ and $1 / 2 \mathrm{Na}^{+}$ions randomly, while $2 \mathrm{~h}$ sites are usually occupied by $\mathrm{Na}^{+}$ions only $[19,20]$. The symmetry of the two 
$\mathrm{Y}^{3+}$ sites is $\mathrm{C}_{3 \mathrm{~h}}$. Thus, the phase transition from $\alpha-\mathrm{NaYF}_{4}$ to $\beta-\mathrm{NaYF}_{4}$ must overcome energy barriers of cation rearrangement, and it, is therefore a disorder-to-order arrangement process. It has been found that $\beta-\mathrm{NaYF}_{4}$ has a more stable crystal structure and better photoluminescence properties than $\alpha-\mathrm{NaYF}_{4}$ [1-3], which has resulted in $\beta-\mathrm{NaYF}_{4}$ receiving more attention from researchers. However, $\mathrm{Ln}^{3+}$ ions (e.g., $\mathrm{Eu}^{3+}, \mathrm{Tb}^{3+}, \mathrm{Dy}^{3+}$, etc.) have a relatively small optical absorption cross section and a narrow absorption spectrum because of the forbidden nature of the $\mathrm{f}-\mathrm{f}$ transition. Thus the intrinsic photoluminescence of $\mathrm{Ln}^{3+}$ ions in $\mathrm{Ln}^{3+}$-doped $\beta-\mathrm{NaYF}_{4}$ phosphors is limited [21]. So far, numerous methods have been studied to enhance the absorption and photoluminescence intensity of $\mathrm{Ln}^{3+}$-doped $\beta-\mathrm{NaYF}_{4}$ phosphors [22-24], including multiple types of $\mathrm{Ln}^{3+}$-doping and sensitization with organic ligands $[8,25,26]$. In this study, a surfactant was employed to control the morphology of the $\mathrm{Ln}^{3+}$-doped $\beta-\mathrm{NaYF}_{4}$ phosphors, and their photoluminescence properties were enhanced.

$\mathrm{Ln}^{3+}$-doped $\beta-\mathrm{NaYF}_{4}$ phosphors, in both micro-sized and nano-sized scales, have been previously synthesized using different methods, such as the molten salt method [27], thermal decomposition of organic precursors [28], sol-gel [17,29], and the hydrothermal/solvothermal method [30]. Some researchers $[2,12,30,31]$ prepared $\mathrm{NaYF}_{4}$ crystals using the hydrothermal/solvothermal method in a water/alcohol/oleic acid system, while others [32] prepared two kinds of $\mathrm{NaYF}_{4}$ particles with different phase composition using an adjustable solvothermal method and by changing reaction temperature and molar ratio $\left(\mathrm{Y}^{3+} / \mathrm{F}^{-}\right)$with a different phase composition. NaYF 4 nanorods, nanotubes, and nanodisks were prepared using oleic acid as hydrothermal synthesis-mediated agent [33], and UC $\beta-\mathrm{NaYF}_{4}: \mathrm{Yb}^{3+} / \mathrm{Er}^{3+}$ microcrystals were synthesized using the hydrothermal method at $220{ }^{\circ} \mathrm{C}$ [34]. However, it is still difficult to obtain $\mathrm{Ln}^{3+}$-doped $\beta-\mathrm{NaYF}_{4}$ particles with uniform and regular shape, high crystallinity, and strong photoluminescence performance. Moreover, these reported hydrothermal/solvothermal processes need either a high temperature or a long reaction time, which is neither economical nor environmentally friendly.

In this study, a simple and convenient solvothermal method was employed to synthesize highly dispersed $\mathrm{Eu}^{3+}$-doped $\beta-\mathrm{NaYF}_{4}$ crystals of micron and submicron size, with controlled morphology and strong photoluminescence. The preparation method was based on our previous work of $\alpha-\mathrm{NaYF}_{4}: \mathrm{Eu}^{3+}$, which had used ethylene glycol/ethanol as a solvent [8]. Oleic acid (OA) was used as a surfactant to control the shape and morphology of the $\beta-\mathrm{NaYF}_{4}: \mathrm{Eu}^{3+}$ microcrystals with enhanced photoluminescence properties. Hexagonal prism bipyramidal $\beta-\mathrm{NaYF}_{4}: \mathrm{Eu}^{3+}$ crystals with uniform particle size of micron and submicron scale were successfully synthesized. The different characteristics of the phase structures, microstructural characteristics, and photoluminescence properties between the as-synthesized $\beta-\mathrm{NaYF}_{4}: \mathrm{Eu}^{3+}$ particles and those modified by $\mathrm{OA}$ were compared in detail. The mechanisms for their shape control, morphology optimization, and photoluminescence enhancement are discussed.

\section{Method}

\subsection{Materials}

Yttrium nitrate $\left(\mathrm{Y}\left(\mathrm{NO}_{3}\right)_{3} \cdot 6 \mathrm{H}_{2} \mathrm{O}, 99.99 \%\right)$, europium nitrate $\left(\mathrm{Eu}\left(\mathrm{NO}_{3}\right)_{3} \cdot 6 \mathrm{H}_{2} \mathrm{O}, 99.99 \%\right)$, sodium nitrate $\left(\mathrm{NaNO}_{3}\right)$ (analytical grade, A.R.), and ammonium fluoride $\left(\mathrm{NH}_{4} \mathrm{~F}\right)$ (A.R.) were used as the raw materials. OA (A.R.) was used as a surfactant, and ethylene glycol (EG, $\mathrm{C}_{2} \mathrm{H}_{6} \mathrm{O}_{2}$, A.R.) and absolute ethanol $\left(\mathrm{C}_{2} \mathrm{H}_{5} \mathrm{OH}, \mathrm{A} . \mathrm{R}\right.$.) were used as the solvents. All chemicals were used as received, without further purification. Deionized water was used throughout this work.

\subsection{Synthesis of $\beta$-NaYF $\mathrm{Eu}_{4}^{3+}$ Crystals without Surfactant}

The $\beta-\mathrm{NaYF}_{4}: \mathrm{Eu}^{3+}$ crystals were synthesized using a solvothermal method as previously described [8]. The doping concentration was $5 \mathrm{~atm} \%$ with the formula $\beta-\mathrm{NaY}_{0.95} \mathrm{Eu}_{0.05} \mathrm{~F}_{4}$. In a typical procedure, $\mathrm{Y}\left(\mathrm{NO}_{3}\right)_{3} \cdot 6 \mathrm{H}_{2} \mathrm{O}(0.7277 \mathrm{~g}$, or $1.9 \mathrm{mmol}), \mathrm{Eu}\left(\mathrm{NO}_{3}\right)_{3} \cdot 6 \mathrm{H}_{2} \mathrm{O}(0.0446 \mathrm{~g}$, or $0.1 \mathrm{mmol})$, and $\mathrm{NaNO}_{3}(0.1700 \mathrm{~g}$, or $2 \mathrm{mmol})$ were mixed and thoroughly dissolved in $15 \mathrm{~mL}$ EG to form a clear 
solution $\mathrm{A}$ at room temperature. $\mathrm{NH}_{4} \mathrm{~F}(1.7779 \mathrm{~g}$, or $48 \mathrm{mmol})$ was added to a $15 \mathrm{~mL}$ EG solution to form solution $\mathrm{B}$ at room temperature. It was found that the phase structure of the synthesized $\mathrm{NaYF}_{4}$ strongly depended on the $\mathrm{Y}^{3+}: \mathrm{F}^{-}$molar ratio in the reaction system. To obtain $\beta-\mathrm{NaYF}_{4}: \mathrm{Eu}^{3+}$ crystals, the molar ratio of $\mathrm{Ln}^{3+}$ ions $\left(\mathrm{Y}^{3+}+\mathrm{Eu}^{3+}\right)$ in solution $\mathrm{A}$ to $\mathrm{F}^{-}$ions in solution $\mathrm{B}$ was set as $\mathrm{Ln}^{3+}: \mathrm{F}^{-}$ $=1: 24$. Solutions $\mathrm{A}$ and $\mathrm{B}$ were mixed under vigorous stirring for $2 \mathrm{~h}$ to form a mixture solution, which was poured into a $50 \mathrm{~mL}$ Teflon-lined stainless steel autoclave and heated at $180^{\circ} \mathrm{C}$ for $6 \mathrm{~h}$ to synthesize $\beta-\mathrm{NaYF}_{4}: \mathrm{Eu}^{3+}$ crystals. After they were cooled down, the resultant $\beta-\mathrm{NaYF}_{4}: \mathrm{Eu}^{3+}$ crystals were collected in a similar manner as described previously [8]. The undoped $\beta-\mathrm{NaYF}_{4}$ crystals were synthesized as the standard sample, following the above procedure, except that no $\mathrm{Eu}^{3+}$ was used.

\subsection{Synthesis of $\beta-\mathrm{NaYF}_{4}: \mathrm{Eu}^{3+}$ Crystals with the Aid of an OA Surfactant}

OA was introduced into the synthesis as a surfactant to control the morphology and improve the photoluminescence of the $\beta-\mathrm{NaYF}_{4}: \mathrm{Eu}^{3+}$ crystals. The synthesis procedure was the same as the above procedure for non-surfactant synthesis (Section 2.2), with the following two modifications. First, $5 \mathrm{~mL}$ of OA was added to solution A. Second, the $15 \mathrm{~mL}$ of EG of solution A had two sets of OA additions: (1) $15 \mathrm{~mL}$ of EG, or (2) $2.5 \mathrm{~mL}$ of absolute ethanol and $12.5 \mathrm{~mL}$ of EG. Thus, two $\beta-\mathrm{NaYF}_{4}: \mathrm{Eu}^{3+}$ samples modified by an OA surfactant were synthesized with the two sets of OA additions.

\subsection{Characterization}

X-ray diffraction (XRD, PANalytical, Empyrean) and field emission scanning electron microscopy (FESEM, FEI-Quanta200F, Thermo Fisher, Waltham, MA, USA) were used to study the phase structures and observe the microstructural characteristics of the $\beta-\mathrm{NaYF}_{4}: \mathrm{Eu}^{3+}$ crystals. The $\mathrm{X}$-ray diffractometer, equipped with graphite-monochromatized $\mathrm{Cu} \mathrm{K} \alpha$ radiation $(\lambda=1.5406 \AA)$ was operated at the scanning step of $0.0131303^{\circ}$ in the $2 \theta$ range from $10^{\circ}$ to $90^{\circ}$. The photoluminescence excitation and emission spectra were recorded with a Hitachi F-4600 fluorescence spectrophotometer (Hitachi, Tokyo, Japan) equipped with a xenon lamp source. All of the measurements in this work were conducted at room temperature.

\section{Results and Discussion}

\subsection{Phase Structures and Microstructural Characteristics}

Figure 1 shows the $\mathrm{XRD}$ patterns of the as-synthesized $\mathrm{NaYF}_{4}$ crystals prepared using different $\mathrm{Y}^{3+}: \mathrm{F}^{-}$molar ratios. The Joint Committee on Powder Diffraction Standards (JCPDS) data for the cubic $\left(\alpha-\mathrm{NaYF}_{4}, \mathrm{PDF} 77-2042\right)$ and hexagonal $\left(\beta-\mathrm{NaYF}_{4}, \mathrm{PDF} 16-0334\right)$ crystal structure of $\mathrm{NaYF}_{4}$ are included in Figure 1 for reference. As shown in Figure 1, only the $\alpha-\mathrm{NaYF}_{4}$ phase could be obtained when $\mathrm{Y}^{3+}: \mathrm{F}^{-}=1: 12$, while mixed phases of $\alpha-\mathrm{NaYF}_{4}$ and $\beta-\mathrm{NaYF}_{4}$ were present when $\mathrm{Y}^{3+}: \mathrm{F}^{-}=1: 16$ and 1:20. When $\mathrm{Y}^{3+}: \mathrm{F}^{-} \geq 1: 24$, only the $\beta-\mathrm{NaYF}_{4}$ phase was obtained. This suggests that the crystal structure of $\mathrm{NaYF}_{4}$ strongly depends on the $\mathrm{Y}^{3+}: \mathrm{F}^{-}$molar ratios in the reaction solution. For this reason, the $\mathrm{Y}^{3+}: \mathrm{F}^{-}$ratio was set at 1:24 to synthesize $\beta-\mathrm{NaYF}_{4}: \mathrm{Eu}^{3+}$ in this study.

Figure 2 shows the XRD patterns of the as-synthesized $\beta-\mathrm{NaYF}_{4}: \mathrm{Eu}^{3+}$ crystals prepared without $\mathrm{OA}$, with $5 \mathrm{~mL} \mathrm{OA}$ and with $5 \mathrm{~mL} \mathrm{OA}+2.5 \mathrm{~mL} \mathrm{C}_{2} \mathrm{H}_{5} \mathrm{OH}$. All of the diffraction peaks (Figure 2) can be readily indexed to the pure hexagonal $\mathrm{NaYF}_{4}$ phase, and no secondary phase was observed in all samples. The sharp diffraction peaks in Figure 2 imply that all of the $\beta-\mathrm{NaYF}_{4}: \mathrm{Eu}^{3+}$ particles were well crystallized. As seen in Figure 2, all of the XRD patterns were relatively similar, which suggests that the utilization of an OA surfactant did not have a noticeable impact on the crystal structures of the $\beta-\mathrm{NaYF}_{4}: \mathrm{Eu}^{3+}$ crystals. Furthermore, the use of $\mathrm{C}_{2} \mathrm{H}_{5} \mathrm{OH}$ also had little influence on their crystal structures. 


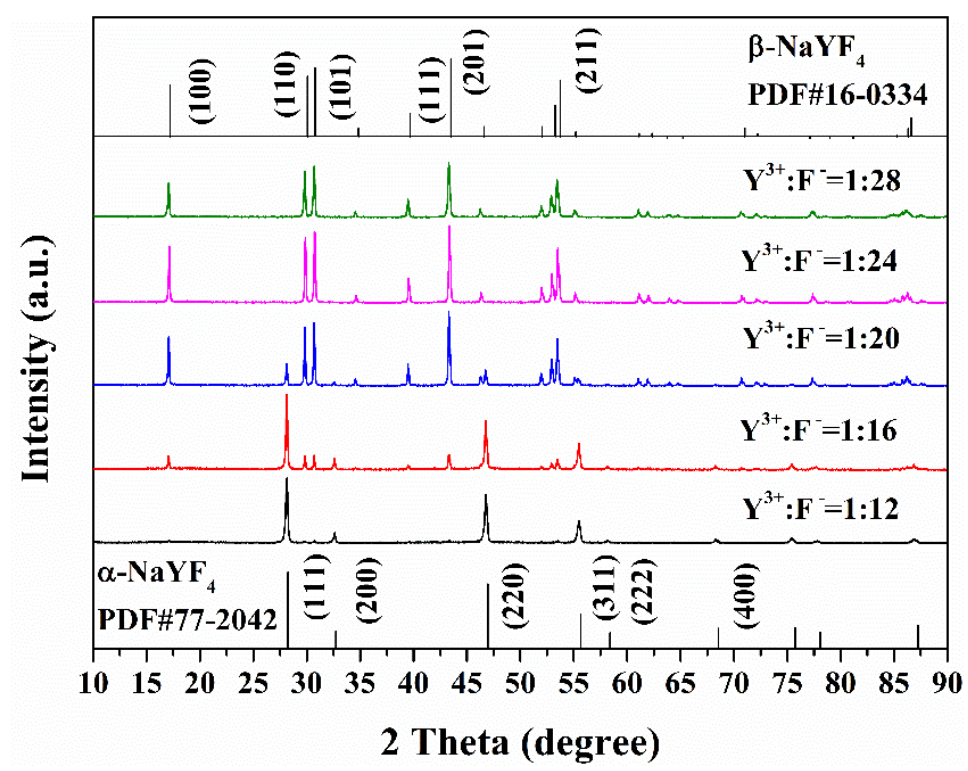

Figure 1. XRD patterns of $\mathrm{NaYF}_{4}$ prepared with different $\mathrm{Y}^{3+}: \mathrm{F}^{-}$molar ratios in the reaction solution.

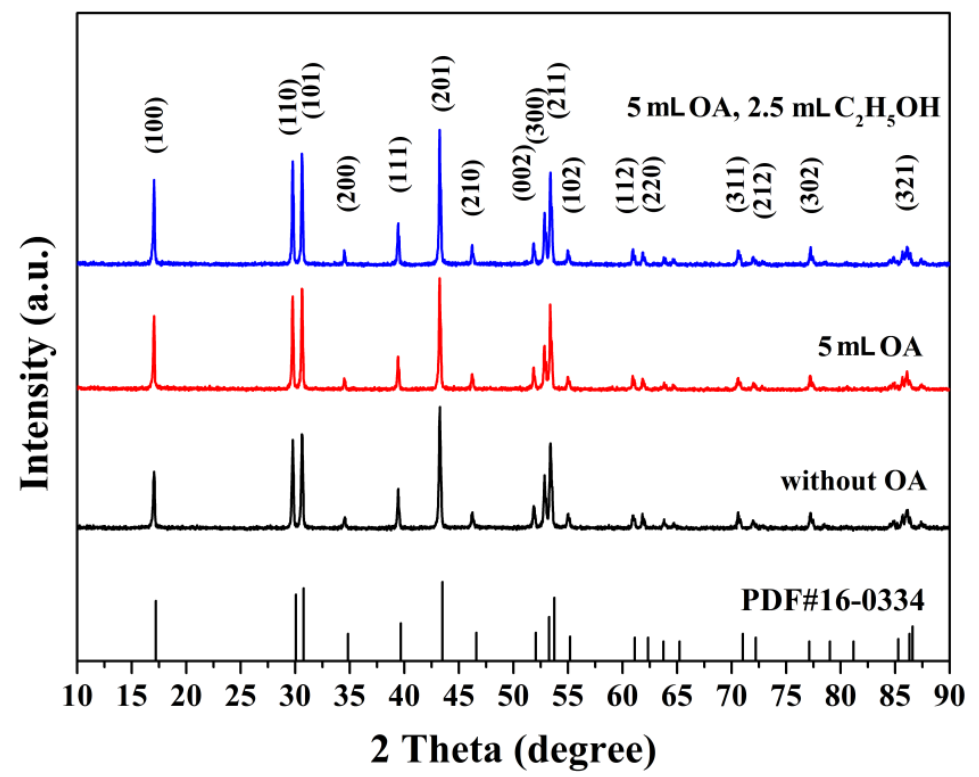

Figure 2. XRD patterns of $\beta-\mathrm{NaYF}_{4}: \mathrm{Eu}^{3+}$, prepared without oleic acid (OA), with $5 \mathrm{~mL}$ OA, and with $5 \mathrm{~mL} \mathrm{OA}+2.5 \mathrm{~mL} \mathrm{C}_{2} \mathrm{H}_{5} \mathrm{OH}$.

The SEM images in Figure 3 show the microstructural characteristics of the as-prepared $\beta-\mathrm{NaYF}_{4}: \mathrm{Eu}^{3+}$ particles. All of the $\beta-\mathrm{NaYF}_{4}: \mathrm{Eu}^{3+}$ particles were highly dispersible. The $\beta-\mathrm{NaYF}_{4}: \mathrm{Eu}^{3+}$ particles prepared without an OA surfactant were the largest (Figure 3a), which was about $1.5 \mu \mathrm{m}$. As shown in Figure $3 b, c$, the utilization of an OA surfactant in the reaction solution greatly reduced the size of the $\beta-\mathrm{NaYF}_{4}: \mathrm{Eu}^{3+}$ particles. The average $\mathrm{NaYF}_{4}: \mathrm{Eu}^{3+}$ particle size, prepared with $5 \mathrm{~mL}$ of $\mathrm{OA}$ and $5 \mathrm{~mL}$ of $\mathrm{OA}+2.5 \mathrm{~mL}$ of $\mathrm{C}_{2} \mathrm{H}_{5} \mathrm{OH}$ was about $650 \mathrm{~nm}$ and $500 \mathrm{~nm}$ (Figure 3b,c), respectively. Thus, adding $\mathrm{C}_{2} \mathrm{H}_{5} \mathrm{OH}$ further reduced the size of the $\beta-\mathrm{NaYF}_{4}: \mathrm{Eu}^{3+}$ particles. 

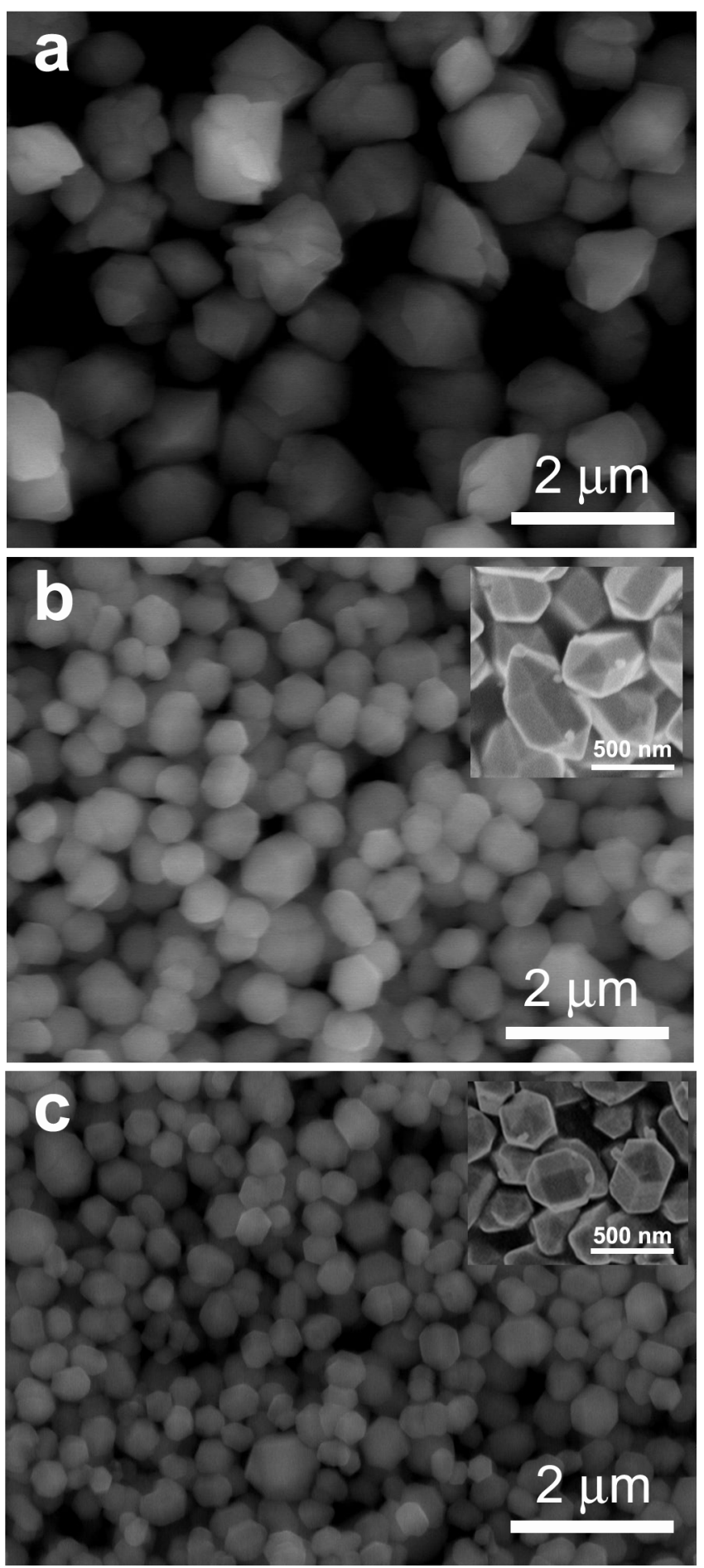

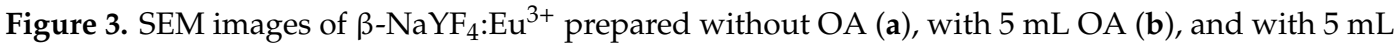
$\mathrm{OA}+2.5 \mathrm{~mL} \mathrm{C}_{2} \mathrm{H}_{5} \mathrm{OH}(\mathbf{c})$.

As seen in Figure 3a, the $\beta-\mathrm{NaYF}_{4}: \mathrm{Eu}^{3+}$ particles, prepared without using an OA surfactant had irregular shapes with rough surfaces. However, the $\beta-\mathrm{NaYF}_{4}: \mathrm{Eu}^{3+}$ particles prepared with an OA surfactant were regular and uniform hexagonal prism bipyramids [34] with smooth surfaces (insets of Figure $3 b, c)$. Thus, the OA surfactant not only reduced the particle size of $\beta-\mathrm{NaYF}_{4}: \mathrm{Eu}^{3+}$ from the micrometer range to submicron scale, it also greatly improved their morphologies. Note that the hexagonal prism bipyramid shape is derived from top and bottom halves, where each half is a six-sided prism. The hexagonal prism bipyramid structure of $\beta-\mathrm{NaYF}_{4}: \mathrm{Eu}^{3+}$ found in this experiment is similar 
to the $\beta-\mathrm{NaYF}_{4}: \mathrm{Yb}$,Er micro-bipyramids shown by Ding et al. [34]. Their research [34] also proposed a possible morphology evolution mechanism for the $\beta-\mathrm{NaYF}_{4}: \mathrm{Yb}$,Er micro-bipyramids, as illustrated in Figure 4. As pointed out by Liang et al. [2], the OA molecules are coated onto the outer face of the generated $\mathrm{NaYF}_{4}$ particles during the early reaction process through the interaction between $\mathrm{Ln}^{3+}$ $\left(\mathrm{Y}^{3+}, \mathrm{Eu}^{3+}\right)$ and the carboxyl of the OA, with the hydrophobic alkyl chains left outside. This interaction can be weakened under high temperature and pressure during the solvothermal process to allow for the $\mathrm{Ln}^{3+}$ ions to be released gradually. The cubic $\alpha-\mathrm{NaYF}_{4}$ is grown first, and these particles usually have an isotropic shape. Because $\alpha-\mathrm{NaYF}_{4}$ is unstable, a more stable $\beta-\mathrm{NaYF}_{4}$ is formed through an $\alpha \rightarrow \beta$ phase transformation during the ongoing reaction process [34]. Eventually, hexagonal prisms are formed [34].

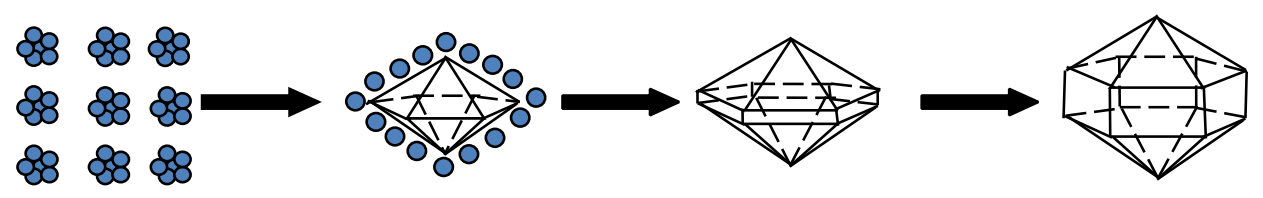

Figure 4. Illustration of the formation and evolution process of the $\beta-\mathrm{NaYF}_{4}: \mathrm{Eu}^{3+}$ hexagonal prism bipyramids (redrawn under the written permission of Prof. Chunhua Lu [34]).

The main reason for the reduced particle size of $\beta-\mathrm{NaYF}_{4}: \mathrm{Eu}^{3+}$ when using a surfactant is that $\mathrm{OA}$ covers the surface of the particles through the interaction between carboxyl and $\mathrm{Eu}^{3+}$ ions (Figure 3). Adding a small amount of $\mathrm{C}_{2} \mathrm{H}_{5} \mathrm{OH}$ into the reaction solution can further reduce the particle size because $\mathrm{C}_{2} \mathrm{H}_{5} \mathrm{OH}$ has a low boiling point, which boosts the internal pressure and consequentially improves the activity of ions. As a result, a large number of crystal nuclei form rapidly in a short time. Furthermore, the crystal nuclei will collide with each other violently, resulting in aggregation and uneven particle growth, which can be gradually uniformed to become microcrystals with increasing reaction time.

\subsection{Photoluminescence Properties}

Figure 5 shows the photoluminescence excitation and emission spectra of the three $\beta-\mathrm{NaYF}_{4}: \mathrm{Eu}^{3+}$ samples prepared without $\mathrm{OA}$, with $5 \mathrm{~mL} \mathrm{OA}$, and with $5 \mathrm{~mL} \mathrm{OA}+2.5 \mathrm{~mL} \mathrm{C}_{2} \mathrm{H}_{5} \mathrm{OH}$. All of the excitation peaks ranging from 200 to $500 \mathrm{~nm}$ are attributed to the characteristic excitation of $\mathrm{Eu}^{3+}$ ions at $320 \mathrm{~nm}\left({ }^{7} \mathrm{~F}_{0} \rightarrow{ }^{5} \mathrm{H}_{0}\right), 364 \mathrm{~nm}\left({ }^{7} \mathrm{~F}_{0} \rightarrow{ }^{5} \mathrm{D}_{4}\right), 379 \mathrm{~nm}\left({ }^{7} \mathrm{~F}_{0} \rightarrow{ }^{5} \mathrm{G}_{2}\right), 397 \mathrm{~nm}\left({ }^{7} \mathrm{~F}_{0} \rightarrow{ }^{5} \mathrm{~L}_{6}\right), 418 \mathrm{~nm}\left({ }^{7} \mathrm{~F}_{0} \rightarrow{ }^{5} \mathrm{D}_{3}\right)$, and $468 \mathrm{~nm}\left({ }^{7} \mathrm{~F}_{0} \rightarrow{ }^{5} \mathrm{D}_{2}\right)$ [8]. The strongest excitation peak originates from the ${ }^{7} \mathrm{~F}_{0} \rightarrow{ }^{5} \mathrm{~L}_{6}$ transition. Similarly, the emission peaks excited by an exciting light at $397 \mathrm{~nm}$ are the characteristic emissions of $\mathrm{Eu}^{3+}$ ions, and they are assigned to the high-energy transition ${ }^{5} \mathrm{D}_{2} \rightarrow{ }^{7} \mathrm{~F}_{3}$ at $515 \mathrm{~nm}$ and ${ }^{5} \mathrm{D}_{1} \rightarrow{ }^{7} \mathrm{~F}_{\mathrm{J}}(\mathrm{J}=0-2)$ at $530 \mathrm{~nm}, 541 \mathrm{~nm}$, and $561 \mathrm{~nm}$; low-energy transition ${ }^{5} \mathrm{D}_{0} \rightarrow{ }^{7} \mathrm{~F}_{\mathrm{J}}(\mathrm{J}=1-4)$ at $598 \mathrm{~nm}, 622 \mathrm{~nm}, 657 \mathrm{~nm}$, and $702 \mathrm{~nm}$, respectively [8,35]. The weaker emission peak at $598 \mathrm{~nm}$ corresponding to ${ }^{5} \mathrm{D}_{0} \rightarrow{ }^{7} \mathrm{~F}_{1}$ is allowed by the magnetic dipole transitions due to $\mathrm{Eu}^{3+}$ ions, located at a site with inversion symmetry, while the stronger emission peak at $622 \mathrm{~nm}$, corresponding to ${ }^{5} \mathrm{D}_{0} \rightarrow{ }^{7} \mathrm{~F}_{2}$, is allowed by the electric dipole transitions that are a result of absence of inversion symmetry at the Eu ${ }^{3+}$ lattice site [36-39].

As seen in Figure 5, the utilization of OA during the synthesis enhanced the photoluminescence intensity of the $\beta-\mathrm{NaYF}_{4}: \mathrm{Eu}^{3+}$ crystals by about $20 \%$. The $\beta-\mathrm{NaYF}_{4}: \mathrm{Eu}^{3+}$ crystals prepared with either $5 \mathrm{~mL}$ OA or with $5 \mathrm{~mL} \mathrm{OA}+2.5 \mathrm{~mL} \mathrm{C}_{2} \mathrm{H}_{5} \mathrm{OH}$ had comparable photoluminescence intensity (Figure 5), with the latter being slightly higher than the former. The reason why OA can improve the photoluminescence of the $\beta-\mathrm{NaYF}_{4}: \mathrm{Eu}^{3+}$ crystals could be explained as follows. The $\beta-\mathrm{NaYF}_{4}: \mathrm{Eu}^{3+}$ crystals prepared with OA had a smoother surface and more integrated uniform shape than the ones prepared without using OA (Figure 3). Thus, the former should have a lower density of non-radiative traps on the surface than the latter, and therefore the former is expected to have stronger photoluminescence. 


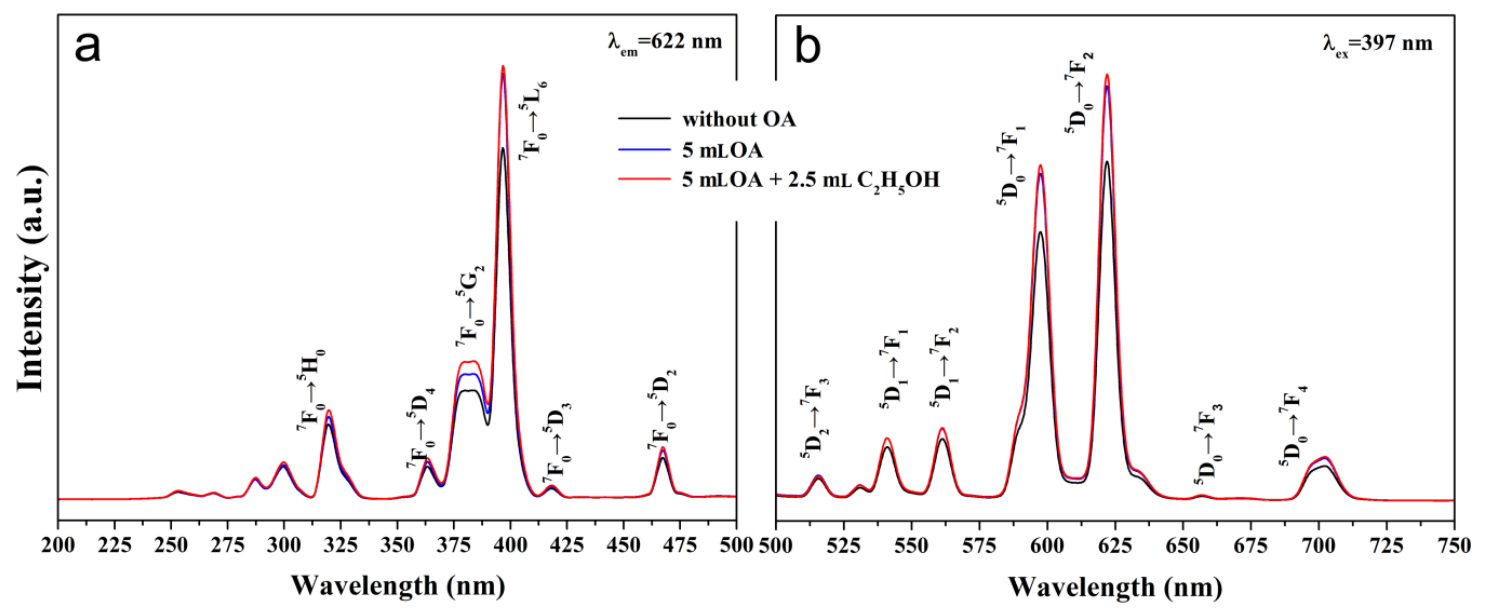

Figure 5. Excitation (a) and emission (b) spectra of the $\beta-\mathrm{NaYF}_{4}: \mathrm{Eu}^{3+}$ crystals prepared without OA, with $5 \mathrm{~mL} \mathrm{OA}$, and with $5 \mathrm{~mL} \mathrm{OA}+2.5 \mathrm{~mL} \mathrm{C}_{2} \mathrm{H}_{5} \mathrm{OH}$.

\section{Conclusions}

In summary, highly crystallized $\beta-\mathrm{NaYF}_{4}: \mathrm{Eu}^{3+}$ crystals with micron and submicron scale were successfully synthesized using the solvothermal method, with ethylene glycol as the solvent. The characteristics of the $\beta-\mathrm{NaYF}_{4}: \mathrm{Eu}^{3+}$ crystals synthesized with and without the use of oleic acid as a surfactant during their synthesis were compared. The utilization of OA as a surfactant during the synthesis of the $\beta-\mathrm{NaYF}_{4}: \mathrm{Eu}^{3+}$ crystals was found to greatly decrease their particle size from about $1.5 \mu \mathrm{m}$ to about $650 \mathrm{~nm}$. Adding small amount of ethanol could further decrease the particle to about $500 \mathrm{~nm}$. In addition, the $\beta-\mathrm{NaYF}_{4}: \mathrm{Eu}^{3+}$ crystals synthesized with the aid of OA as a surfactant also exhibited much smoother surfaces and more uniform morphologies, which were hexagonal prism bipyramids. The present study also found that the $\beta-\mathrm{NaYF}_{4}: \mathrm{Eu}^{3+}$ crystals prepared with the aid of OA as a surfactant during their synthesis exhibited about $20 \%$ stronger photoluminescence than those synthesized without using an OA surfactant.

Author Contributions: J.H., X.W. and A.S. conducted the investigation and analysis work, and they wrote the manuscript draft. G.D. and N.C. designed the method and ssupervised the work. G.D. provided the funding for this work.

Funding: This work was supported by the National Natural Science Foundation of China (21571095) and the Scientific Research Projects of Hunan Education Department (No. 18C1442).

Conflicts of Interest: The authors declare no conflict of interest.

\section{References}

1. Chen, D.Q.; Huang, P.; Yu, Y.L.; Huang, F.; Yang, A.P.; Wang, Y.S. Dopant-induced phase transition: A new strategy of synthesizing hexagonal upconversion $\mathrm{NaYF}_{4}$ at low temperature. Chem. Commun. (Camb. Engl.) 2011, 47, 5801-5803. [CrossRef] [PubMed]

2. Liang, X.; Wang, X.; Zhuang, J.; Peng, Q.; Li, Y. Synthesis of $\mathrm{NaYF}_{4}$ nanocrystals with predictable phase and shape. Adv. Funct. Mater. 2007, 17, 2757-2765. [CrossRef]

3. Reddy, K.N.; Jafaruddin, M.D. Decay behaviour of $\mathrm{NaYF}_{4}$ : Gd ${ }^{3+}$ phosphors. J. Mater. Sci. Lett. 1983, 2, 296-298. [CrossRef]

4. Tu, D.; Liu, Y.; Zhu, H.; Li, R.; Liu, L.; Chen, X. Breakdown of crystallographic site symmetry in lanthanide-doped $\mathrm{NaYF}_{4}$ crystals. Angew. Chem. Int. Ed. 2013, 52, 1128-1133. [CrossRef] [PubMed]

5. Wang, L.; Li, L. Controlled synthesis and luminescence of lanthanide doped $\mathrm{NaYF}_{4}$ nanocrystals. Chem. Mater. 2007, 19, 727-734. [CrossRef]

6. Wang, G.; Qin, W.; Zhang, J.; Wang, L.; Wei, G.; Zhu, P. Controlled synthesis and luminescence properties from cubic to hexagonal $\mathrm{NaYF}_{4}: \mathrm{Ln}^{3+}(\mathrm{Ln}=\mathrm{Eu}$ and $\mathrm{Yb} / \mathrm{Tm}$ ) microcrystals. J. Alloys Compd. 2009, 475, 452-455. [CrossRef] 
7. Podhorodecki, A.; Banski, M.; Misiewicz, J.; Afzaal, M.; O'Brien, P.; Cha, D. Multicolor light emitters based on energy exchange between $\mathrm{Tb}$ and $\mathrm{Eu}$ ions co-doped into ultrasmall $\beta-\mathrm{NaYF}_{4}$ nanocrystals. J. Mater. Chem. 2012, 22, 5356-5361. [CrossRef]

8. Yu, W.; Wang, X.; Chen, N.; Du, G.; Gui, W. A strategy to prepare highly redispersible and strongly luminescent $\alpha-\mathrm{NaYF}_{4}: \mathrm{Eu}^{3+}$ hybrid nanostructures with multi-channel excitation. CrystEngComm 2014, 16, 3214-3221. [CrossRef]

9. Li, C.; Zhang, C.; Hou, Z.; Wang, L.; Quan, Z.; Lian, H.; Lin, J. $\beta-N^{-} Y_{F}$ and $\beta-N_{a} F_{4}: E^{3+}$ microstructures: Morphology control and tunable luminescence properties. J. Phys. Chem. C 2009, 113, 2332-2339. [CrossRef]

10. Liu, Y.; Ai, K.; Lu, L. Designing lanthanide-doped nanocrystals with both up- and down-conversion luminescence for anti-counterfeiting. Nanoscale 2011, 3, 4804-4810. [CrossRef] [PubMed]

11. Ding, M.; Zhang, D.; Chen, Q.H.; Xi, J.H.; Ji, Z. Color-tunable luminescence, energy transfer and temperature sensing behavior of hexagonal $\mathrm{NaYF}_{4}: \mathrm{Ce}^{3+} / \mathrm{Tb}^{3+} / \mathrm{Eu}^{3+}$ microcrystals. J. Alloys Compd. 2016, 672, 117-124. [CrossRef]

12. Wang, L.; $\mathrm{Li}, \mathrm{Y} . \mathrm{Na}\left(\mathrm{Y}_{1.5} \mathrm{Na}_{0.5}\right) \mathrm{F}_{6}$ single-crystal nanorods as muticolor luminescent materials. Nano Lett. 2006, 6, 1645-1649. [CrossRef] [PubMed]

13. Li, Z.; Zhang, Y. An efficient and user-friendly method for the synthesis of hexagonal-phase $\mathrm{NaYF}(4): \mathrm{Yb}$, $\mathrm{Er} / \mathrm{Tm}$ nanocrystals with controllable shape and upconversion fluorescence. Nanotechnology 2008, 19, 345606. [CrossRef] [PubMed]

14. Li, Z.; Zhang, Y.; Jiang, S. Multicolor core/shell-structured upconversion fluorescent nanoparticles. Adv. Mater. 2008, 20, 4765-4769. [CrossRef]

15. He, M.; Huang, P.; Zhang, C.; Ma, J.; He, R.; Cui, D. Phase- and size-controllable synthesis of hexagonal upconversion rare-earth fluoride nanocrystals through an oleic acid/ionic liquid two-phase system. Chem. Eur. J. 2012, 18, 5954-5969. [CrossRef] [PubMed]

16. Huang, Q.M.; Yu, H.; Ma, E.; Zhang, X.Q.; Cao, W.B.; Yang, C.G.; Yu, J.C. Upconversion effective enhancement by producing various coordination surroundings of rare-earth ions. Inorg. Chem. 2015, 54, 2643-2651. [CrossRef] [PubMed]

17. Santana-Alonso, A.; Yanes, A.C.; Méndez-Ramos, J.; del-Castillo, J.; Rodríguez, V.D. Sol-gel transparent nano-glass-ceramics containing $\mathrm{Eu}^{3+}$-doped $\mathrm{NaYF}_{4}$ nanocrystals. J. Non-Cryst. Solids 2010, 356, 933-936. [CrossRef]

18. Reddy, K.N.; Shareef, M.A.H.; Pandaraiah, N. Growth and X-ray study of $\mathrm{NaYF}_{4}$ crystals. J. Mater. Sci. Lett. 1983, 2, 83-84. [CrossRef]

19. Burns, J.H. Crystal structure of hexagonal sodium neodymium fluoride and related compounds. Inorg. Chem. 1965, 4, 881-886. [CrossRef]

20. Grzechnik, A.; Bouvier, P.; Mezouar, M.; Mathews, M.D.; Tyagi, A.K.; Köhler, J. Hexagonal Na $\mathrm{Na}_{1.5} \mathrm{Y}_{1.5} \mathrm{~F}_{6}$ at high pressures. J. Solid State Chem. 2002, 165, 159-164. [CrossRef]

21. Velasco, D.S.; Moura, A.P.D.; Medina, A.N.; Baesso, M.L.; Rubora, A.F.; Cremona, M. Preparation, characterization, and spectroscopic properties of PC/PMMA doped blends: Study of the effect of rare-earth doping on luminescence, quenching rate, and lifetime enhancement. J. Phys. Chem. B 2010, 114, 5657-5660. [CrossRef] [PubMed]

22. Heer, S.; Kömpe, K.; Güdel, H.U.; Haase, M. Highly efficient multicolour upconversion emission in transparent colloids of Lanthanide-doped $\mathrm{NaYF}_{4}$ nanocrystals. Adv. Mater. 2004, 16, 2102-2105. [CrossRef]

23. Yao, Y.H.; Xu, C.; Zheng, Y.; Yang, C.S.; Liu, P.; Ding, J.X.; Jia, T.Q.; Qiu, J.R.; Zhang, S.; Sun, Z.R. Improving upconversion luminescence efficiency in $\mathrm{Er}^{3+}$-doped NaYF4 nanocrystals by two-color laser field. J. Mater. Sci. 2016, 51, 5460-5468. [CrossRef]

24. Luoshan, M.D.; Bai, L.H.; Bu, C.H.; Liu, X.L.; Zhu, Y.D.; Guo, K.M.; Jiang, R.H.; Li, M.Y.; Zhao, X.Z. Surface plasmon resonance enhanced multi-shell-modified upconversion $\mathrm{NaYF}_{4}: \mathrm{Yb}^{3+}, \mathrm{Er}^{3+} @ \mathrm{SiO}_{2} @ \mathrm{Au} @ \mathrm{TiO}_{2}$ crystallites for dye-sensitized solar cells. J. Power Sour. 2016, 307, 468-473. [CrossRef]

25. Li, S.; Hou, Z.; Cheng, Z.; Lian, H.; Ma, P.A.; Li, C.; Lin, J. Enhanced near-infrared quantum cutting luminescence in 1,2,4,5-benzenetetracarboxylic acid/NaYF $4: \mathrm{Tb}^{3+}, \mathrm{Yb}^{3+}$ hybrid nanoparticles. RSC Adv. 2013, 3, 5491-5497. [CrossRef]

26. Zhang, T.; Lin, H.; Cui, L.; An, N.; Tong, R.; Chen, Y.; Li, X.; Qu, F.Y. NIR-sensitive UCNP@mSiO ${ }_{2}$ nanovehicles for on-demand drug release and photodynamic therapy. RSC Adv. 2016, 6, 26479-26489. [CrossRef] 
27. Zhang, X.; Yang, P.; Li, C.; Wang, D.; Xu, J.; Gai, S.; Lin, J. Facile and mass production synthesis of beta- $\mathrm{NaYF}_{4}: \mathrm{Yb}^{3+}, \mathrm{Er}^{3+} / \mathrm{Tm}^{3+} 1 \mathrm{D}$ microstructures with multicolor up-conversion luminescence. Chem. Commun. (Camb.) 2011, 47, 12143-12145. [CrossRef] [PubMed]

28. Yi, G.S.; Chow, G.M. Synthesis of hexagonal-phase $\mathrm{NaYF}_{4}: \mathrm{Yb}$,Er and $\mathrm{NaYF}_{4}: \mathrm{Yb}, \mathrm{Tm}$ nanocrystals with efficient up-conversion fluorescence. Adv. Funct. Mater. 2006, 16, 2324-2329. [CrossRef]

29. Lochhead, M.J.; Bray, K.L. Rare-earth clustering and Aluminum codoping in sol-gel silica: Investigation using Europium(III) fluorescence spectroscopy. Chem. Mater. 1995, 7, 572-577. [CrossRef]

30. Wang, X.; Zhuang, J.; Peng, Q.; Li, Y. A general strategy for nanocrystal synthesis. Nature 2005, 437, $121-124$. [CrossRef] [PubMed]

31. Liang, X.; Wang, X.; Zhuang, J.; Peng, Q.; Li, Y. Branched NaYF 4 nanocrystals with luminescent properties. Inorg. Chem. 2007, 46, 6050-6055. [CrossRef] [PubMed]

32. Qu, X.; Pan, G.; Yang, H.K.; Chen, Y.; Chung, J.W.; Moon, B.K.; Jeong, J.H. Solvothermal synthesis and luminescence properties of $\mathrm{NaYF}_{4}: \mathrm{Ln}^{3+}\left(\mathrm{Eu}^{3+}, \mathrm{Tb}^{3+}, \mathrm{Yb}^{3+} / \mathrm{Er}^{3+}\right)$ nano- and microstructures. Opt. Mater. 2012, 34, 1007-1012. [CrossRef]

33. Zhang, F.; Wan, Y.; Yu, T.; Zhang, F.; Shi, Y.; Xie, S.; Li, Y.G.; Xu, L.; Tu, B.; Zhao, D.Y. Uniform nanostructured arrays of sodium rare-earth fluorides for highly efficient multicolor upconversion luminescence. Angew. Chem. Int. Ed. Engl. 2007, 46, 7976-7979. [CrossRef] [PubMed]

34. Ding, M.; Lu, C.; Cao, L.; Ni, Y.; Xu, Z. Controllable synthesis, formation mechanism and upconversion luminescence of $\beta-\mathrm{NaYF}_{4}: \mathrm{Yb}^{3+} / \mathrm{Er}^{3+}$ microcrystals by hydrothermal process. CrystEngComm 2013, 15, 8366-8373. [CrossRef]

35. Huignard, A.; Buissette, V.R.; Franville, A.C.; Gacoin, T.; Boilot, J.P. Emission processes in $\mathrm{YVO}_{4}: \mathrm{Eu}$ nanoparticles. J. Phys. Chem. B 2003, 107, 6754-6759. [CrossRef]

36. Stouwdam, J.W.; van Veggel, F.C.J.M. Near-infrared emission of redispersible $\mathrm{Er}^{3+}, \mathrm{Nd}^{3+}$, and $\mathrm{Ho}^{3+}$ doped $\mathrm{LaF}_{3}$ nanoparticles. Nano Lett. 2002, 2, 733-737. [CrossRef]

37. Wang, X.; Yang, Y.; Chen, N.; Liu, B.; Liu, G. Preparation of $\mathrm{LaF}_{3}: \mathrm{Eu}^{3+}$ based inorganic-organic hybrid nanostructures via an ion exchange method and their strong luminescence. J. Nanosci. Nanotechnol. 2016, 16, 3729-3734. [CrossRef] [PubMed]

38. Nogami, M.; Enomoto, T.; Hayakawa, T. Enhanced fluorescence of $\mathrm{Eu}^{3+}$ induced by energy transfer from nanosized $\mathrm{SnO}_{2}$ crystals in glass. J. Lumin. 2002, 97, 147-152. [CrossRef]

39. Zhan, Y.; Du, G.; Chen, N.; Li, Y.; Liu, B.; Liu, G. Photoluminescence properties of $\mathrm{YVO}_{4}: \mathrm{Eu}^{3+}, \mathrm{Ba}^{2+}$ nanoparticles prepared by an ion exchange method. Mater. Sci. Semiconduct. Process. 2016, 41, 233-239. [CrossRef]

(C) 2019 by the authors. Licensee MDPI, Basel, Switzerland. This article is an open access article distributed under the terms and conditions of the Creative Commons Attribution (CC BY) license (http://creativecommons.org/licenses/by/4.0/). 